\title{
An Electron Microscopic Study of Anaerovibrio lipolytica (Strain 5s) and Its Lipolytic Enzyme
}

\author{
By C. HENDERSON \\ Rowett Research Institute, Bucksburn, Aberdeen, AB2 $9 S B$ \\ AND W. HODGKISS \\ Torry Research Station, Aberdeen, AB9 8DG \\ (Received 25 October 1972; revised I 7 January 1973) \\ SUMMAR Y \\ The extracellular lipolytic activity produced by Anaerovibrio lipolytica strain $5 \mathrm{~S}$ \\ is associated with large particles composed of protein, lipid and nucleic acid. These \\ particles have a membranous appearance when viewed by electron microscope \\ and in the ultracentrifuge they have a sedimentation coefficient $\left(s_{20, w}\right)$ of I 3. I S. \\ Numerous 'blebs' are associated with the walls of Anaerovibrio lipolytica during \\ the phase of logarithmic growth when lipase production is maximal. The lipolytic \\ enzyme is released from the bacteria without visible bacterial lysis.
}

\section{INTRODUCTION}

Extracellular enzymes are more commonly produced by Gram-positive than by Gramnegative bacteria (Pollock, 1962) and the secretion of enzymes by Gram-positive bacteria has been linked with mesosomes (Beaton, I968) or with organelles bearing a superficial morphological resemblance to mesosomes (Ghosh, Sargent \& Lampen, I968). Mesosomal material from Gram-positive bacteria has been widely studied. Popkin, Theodore \& Cole (I97I) examined by electron microscopy the mesosomal vesicles released from Staphylococcus aureus during protoplast formation. Ghosh \& Murray (1969) found that mesosomal material from Listeria monocytogenes contained RNA, DNA, phospholipid and protein. A similar study of mesosomal material from Micrococcus lysodeikticus was made by Ellar \& Freer (1969). Mesosomes are most prominent in Gram-positive bacteria but are not exclusive to such organisms and Ryter \& Jacob (1966) and Pontefract, Bergeron \& Thatcher (1969) have reported studies of mesosomes in Escherichia coli.

Anaerovibrio lipolytica strain $5 \mathrm{~S}$, a Gram-negative rumen bacterium, produces an extracellular lipase of large molecular weight (Henderson, 197I). An electron microscopic study of the enzyme has been made and, in an attempt to observe the secretion of enzyme, the bacteria have also been examined by electron microscopy.

\section{METHODS}

Lipase activity was measured as described by Henderson (197r), using olive oil as substrate and employing the extraction and titration method of Cohen, Morgan \& Hofman (1969).

Purification of the extracellular lipase of Anaerovibrio lipolytica. The bacteria were grown in a chemostat under carbon-limited conditions at $38^{\circ} \mathrm{C}$ and a dilution rate of $0 . \mathrm{I}^{2} \mathrm{O} \mathrm{h}^{-1}$ and the outflow medium collected in a glass vessel at $\mathrm{I}^{\circ} \mathrm{C}$. Litre amounts of bacteria-free medium were half-saturated with ammonium sulphate and $2 \%(\mathrm{w} / \mathrm{v})$ of cellulose powder 
added. The suspension was stirred for $3 \mathrm{~h}$ at $\mathrm{I}{ }^{\circ} \mathrm{C}$ and the cellulose removed by centrifugation. A glass column $(320 \times 18 \mathrm{~mm})$ was packed with the wet cellulose and the lipolytic activity eluted in $30 \mathrm{ml} \mathrm{O} \cdot \mathrm{I}$ M-phosphate buffer, $\mathrm{pH} 7 \cdot 4$. After overnight dialysis against distilled water the enzyme solution was concentrated to $6 \mathrm{ml}$ by ultrafiltration through a collodion shell, applied to a Sephadex G 200 column (void volume $80 \mathrm{ml}$ ) and eluted with $0 . \mathrm{I}$ M-phosphate buffer, $\mathrm{pH} 7.4$. The lipase activity was detected in the protein fraction eluted in the void volume of buffer.

Ultracentrifugal separation. Samples of lipase from the Sephadex G 200 column were concentrated by ultrafiltration and solutions, containing $0.75 \%(\mathrm{w} / \mathrm{v})$ dry matter in $0.1 \mathrm{M}-$ phosphate buffer, $\mathrm{pH} \mathrm{7.4}$, were centrifuged at $59780 \mathrm{rev} . / \mathrm{min}$ in a Spinco Model E analytical ultracentrifuge (Beckman-RIIC Ltd, Glenrothes, Scotland). Two components were resolved, the major one having a sedimentation coefficient $\left(s_{20, \mathrm{w}}\right)$ of $5.0 \mathrm{~S}$ and the minor component a sedimentation coefficient I3. I S.

To determine which of the two components separated by ultracentrifugation had lipase activity, preparative ultracentrifugal separations were performed on sucrose density gradients using an SW-50 L rotor in a Beckman L 2-50 ultracentrifuge. Sucrose density gradients were prepared by sequential pipetting into $5 \mathrm{ml}$ cellulose nitrate tubes of $2 \mathrm{ml}$ $30 \%(\mathrm{w} / \mathrm{v})$ sucrose in $0 . \mathrm{I} \mathrm{M}$-phosphate buffer, $\mathrm{pH} \mathrm{7.4,} \mathrm{I} \cdot 5 \mathrm{ml} 25 \%$ sucrose solution and $\mathrm{I} \cdot 0 \mathrm{ml} 20 \%$ sucrose solution. After the layers had interdiffused for $24 \mathrm{~h}$ at I ${ }^{\circ} \mathrm{C}, 0.5 \mathrm{ml}$ of purified lipase solution containing $0.65 \mathrm{mg}$ protein was layered above the sucrose gradient and the tubes were centrifuged at $50000 \mathrm{rev} . / \mathrm{min}$ for $6.0 \mathrm{~h}$. The base of each tube was then punctured with a hypodermic needle and the contents pumped out at $4 \mathrm{ml} / \mathrm{h}$ and collected in $0.25 \mathrm{ml}$ fractions. The $E_{280 \mathrm{~nm}}^{1 \mathrm{~cm}}$, and lipase activity of each fraction was assayed. The lipolytic activity was recovered in the fractions closest to the bottom of the tube which corresponded to the faster-moving minor component observed in the analytical ultracentrifuge.

Examination, by thin-layer chromatography, of chloroform-methanol $(2: \mathrm{I}, \mathrm{v} / \mathrm{v})$ extracts of purified lipase preparations showed that the major lipid component was phosphatidyl ethanolamine. Phosphatidyl ethanolamine was also the major phospholipid in lipid-solvent extracts of washed suspensions of Anaerovibrio lipolytica.

As with the lipase preparations described by Henderson (I97I), the purest preparations obtained in this study contained a high proportion of nucleic acid.

Electron microscopy. Enzyme preparations were dialysed overnight against distilled water and stained by addition of $0.1 \mathrm{ml}$ aqueous phosphotungstic acid (I \%, w/v; adjusted to $\mathrm{pH} \mathrm{7 \cdot 2)}$ to $\mathrm{I} \mathrm{ml}$ of enzyme preparation. A drop of this mixture was placed on a carbonstabilized, formvar-coated copper grid (mesh 200), air-dried, and examined in the electron microscope.

Bacteria were obtained from carbon-limited continuous cultures growing at a dilution rate of $0.120 \mathrm{~h}^{-1}$, or from batch cultures during the early logarithmic phase of growth (Henderson, 1971).

For negatively stained and metal-shadowed specimens the bacteria were fixed for $4 \mathrm{~h}$ at $4{ }^{\circ} \mathrm{C}$ by the addition of formaldehyde (final concentration $2.5 \%, \mathrm{v} / \mathrm{v}$ ) to a sample of culture medium. After fixation, bacteria were washed three times by centrifugation in sterile, distilled water. Negatively stained specimens of fixed bacteria were prepared in the same way as negatively stained enzyme preparations. For metal-shadowed specimens, I drop of washed bacterial suspension was placed on a formvar-coated copper grid (200 mesh) airdried and shadowed with gold + palladium $(40: 60)$ at an angle of $20^{\circ}$.

For ultramicrotomy, bacteria were fixed for $4 \mathrm{~h}$ at $4{ }^{\circ} \mathrm{C}$ by adding $0.5 \mathrm{~g}$ osmium tetroxide 
to $50 \mathrm{ml}$ of culture. The fixed bacteria were washed with veronal buffer, dehydrated with alcohol and embedded in Araldite (Geigy Ltd, Duxford, Cambridge). Sections were cut with glass knives in an LKB Ultratome III and stained with lead oxide (Karnovsky, I96I).

Specimens were examined in a Siemens Elmiskop I electron microscope, using double condenser illumination, a $200 \mu \mathrm{m}$ condenser aperture, $50 \mu \mathrm{m}$ objective aperture and an accelerating voltage of $60 \mathrm{kV}$. Micrographs were recorded on Kodak Electron Image plates.

\section{RESULTS AND DISCUSSION}

The enzyme preparations used in this study were broadly similar to those described by Henderson (1971) in a study of lipase produced by Anaerovibrio lipolytica grown at a lower growth rate.

Samples of enzyme purified by gel filtration on Sephadex G 200 were shown to be membranous in appearance (Fig. I). The particles were of fairly uniform size, and although usually circular, more irregular shapes suggestive of fragmented membranes were occasionally found. In specimens of lipase purified by ultracentrifugation in sucrose density gradients (Fig. 2), particles were uniformly circular and varied in size depending on whether or not sucrose was removed by dialysis.

The possibility that the lipase was released from Anaerovibrio lipolytica by autolytic fragmentation of the bacterial membrane was discounted since an electron microscopic study of whole cultures gave no evidence of lysed bacteria. Fig. 3 shows a typical field on a grid. Also, in batch cultures the lipase appears early in the logarithmic phase of growth when little lysis would have occurred and no lipase is associated with the whole or fragmented bacteria. (Henderson, 1971).

Bacteria harvested from cultures in the early logarithmic phase (Fig. 3,5$)$ and bacteria grown in continuous culture at dilution rate $0.120 \mathrm{~h}^{-1}$ (Fig.4) showed the presence of 'blebs' on the surface. It is suggested that these produce the particles which are obtained when the lipolytic activity is isolated and purified. The blebs were not associated with degenerated bacteria; on the contrary they were most frequently found attached to the area of the crosswall in dividing bacteria.

Thin sections of Anaerovibrio lipolytica were examined to look for possible involvement of mesosomal structures in the secretion of lipase (Fig. 6). However, in a large number of studies no structures were observed in the bacterial membranes which correlated with the 'blebs' observed in examination of whole bacteria. Ryter \& Jacob (1966) indicated that the mesosomes of Gram-negative bacteria were very difficult to observe.

In conclusion we believe that the lipase of Anaerovibrio lipolytica is associated with membranous material of similar phospholipid composition to that of the whole bacteria and that the enzyme is a truly extracellular enzyme, being extruded, by an unknown mechanism, from bacteria which do not lose their structural integrity.

We wish to thank Mr J. Stewart, who operated the analytical ultracentrifuge, and Mr E. Forbes for skilled technical assistance. We also wish to thank Dr P. N. Hobson for helpful discussions. 

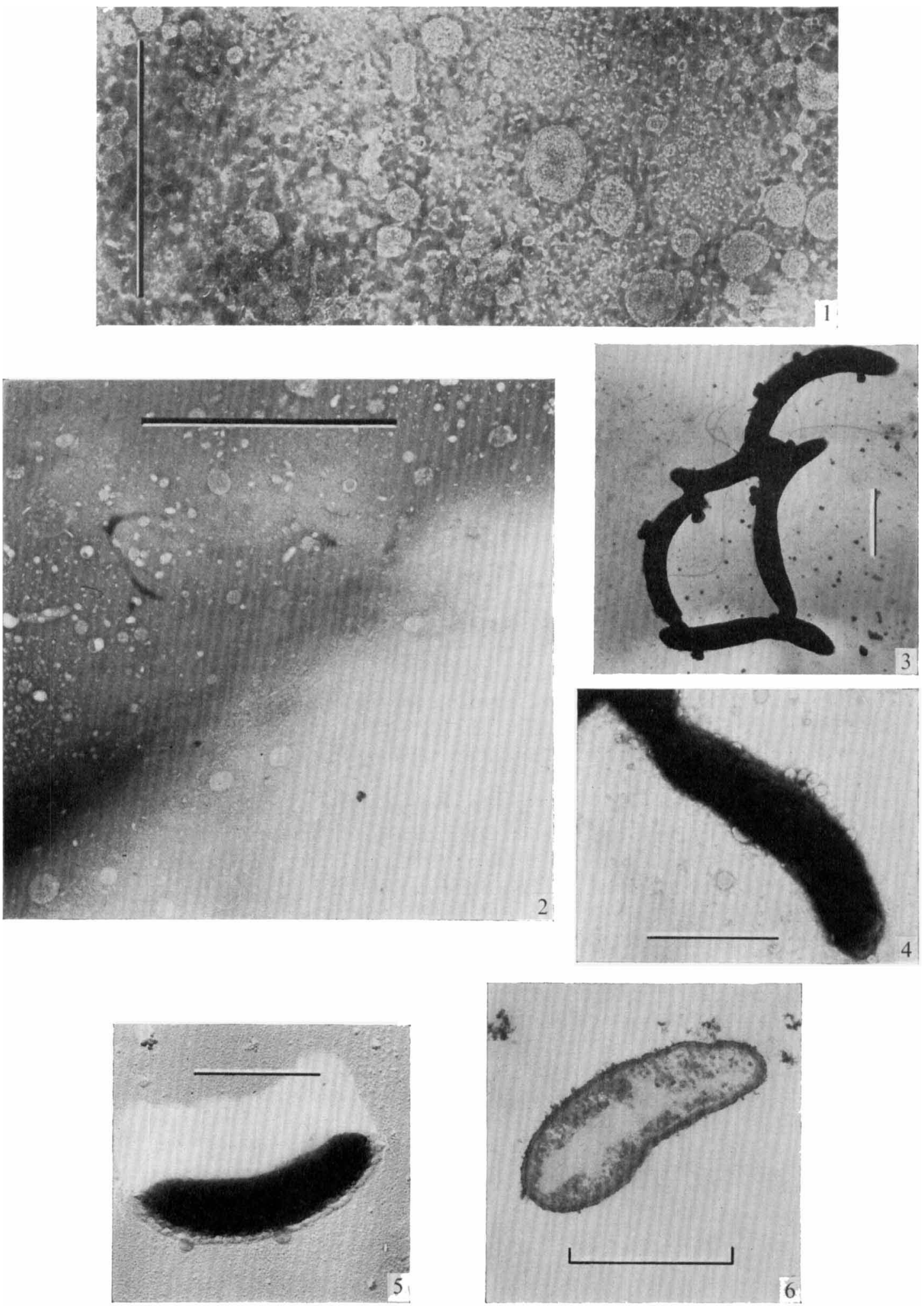


\section{REFERENCES}

BEATON, C. D. (I968). An electron microscope study of the mesosomes of a penicillinase-producing Staphylococcus. Journal of General Microbiology 5o, 37-42.

Cohen, M., Morgan, R. G. H. \& Hofman, A. F. (I969). One-step quantitative extraction of medium-chain and long-chain fatty acids from aqueous samples. Journal of Lipid Research 1o, 614-616.

Ellar, D. J. \& Freer, J. H. (I969). The isolation and characterisation of mesosome material from Micrococcus lysodeikticus. Journal of General Microbiology 58, vii.

GHosh, B. K. \& Murray, R. G. E. (1969). Fractionation and characterisation of the plasma and mesosome membrane of Listeria monocytogenes. Journal of Bacteriology 97, 426-440.

Ghosh, B. K., SARgent, M. G. \& LAMPEN, J. O. (1968). Morphological phenomena associated with penicillinase induction and secretion in Bacillus licheniformis. Journal of Bacteriology 96, 13 14-1328.

Henderson, C. (197I). A study of the lipase produced by Anaerovibrio lipolytica, a rumen bacterium. Journal of General Microbiology 65, 8I-89.

KARNovsky, M. J. (196I). Simple methods for staining with lead at high $\mathrm{pH}$ in electron microscopy. Journal of Biophysical and Biochemical Cytology r1, 729-732.

Pollock, M. R. (1962). Exoenzymes. In The Bacteria, vol. IV, p. I21. Edited by I. C. Gunsalus and R. Y. Stanier. New York: Academic Press.

Pontefract, R. D., Bergeron, G. \& Thatcher, F. S. (I969). Mesosomes in Escherichia coli. Journal of Bacteriology 97, 367-375.

Popkin, T. J., TheOdore, T. S. \& Cole, R. M. (197I). Electron microscopy during release and purification of mesosomal vesicles and protoplast membranes from Staphylococcus aureus. Journal of Bacteriology ro7, 907-917.

RYTER, A. \& JACOB, F. (1966). Étude morphologique de la liaison du noyau à la membrane chez $E$. coli et chez les protoplastes de B. subtilis. Annales de l'Institut Pasteur r1o, 801-8I 2.

Fig. I. Negatively stained preparation of enzyme purified by gel filtration on Sephadex G 200. The marker bar in each photograph is $1 \mu \mathrm{m}$.

Fig. 2. Negatively stained preparation of enzyme purified by ultracentrifugation in sucrose density gradient. Sucrose was removed by dialysis against distilled water prior to staining.

Fig. 3. Negatively stained Anaerovibrio lipolytica harvested in the early stages of the phase of logarithmic growth in a batch culture.

Fig. 4. Negatively stained Anaerovibrio lipolytica from a carbon-limited continuous culture growing at a dilution rate of $0 \cdot 120 \mathrm{~h}^{-1}$.

Fig. 5. Metal shadowed Anaerovibrio lipolytica harvested in the early stages of the phase of logarithmic growth in a batch culture.

Fig. 6. Thin section of Anaerovibrio lipolytica harvested in the early stages of the phase of logarithmic growth in a batch culture. 